\begin{tabular}{c} 
JURNAL SAINS dan INOVASI PERIKANAN \\
Journal of Fishery Science and Innovation \\
e-ISSN: 2502-3276 \\
Vol. 1, No.1, 1-8, Januari 2017 \\
http://ojs.uho.ac.id/index.php/JSIPi \\
\hline PERIKANAN \\
\hline
\end{tabular}

\title{
Struktur Ukuran dan Parameter Populasi Rajungan (Portunus pelagicus, Linnaeus 1758) di Perairan Toronipa, Sulawesi Tenggara, Indonesia
}

\section{Size Structure and Population Parameter of Blue Swimming Crab (Portunus pelagicus, Linnaeus 1758) in Toronipa Waters, Southeast Sulawesi, Indonesia}

\author{
Ari Sandy Muchtar ${ }^{1 *)}$, La Sara $^{2)}$, Asriyana ${ }^{2)}$ \\ ${ }^{1)}$ Mahasiswa Program Studi Magister Ilmu Perikanan Pascasarjana Universitas Halu Oleo \\ ${ }^{2)}$ Fakultas Perikanan dan Ilmu Kelautan Universitas Halu Oleo \\ Corresponding author ${ }^{*}$ : asandy.pon@gmail.com; lasara_unhalu@yahoo.com;
}

\begin{abstract}
The aim of study was to analyze size structure and population parameters of blue swimming crabs ( $P$. pelagicus) in the Toronipa waters which was conducted from March to August 2014. Total of samples obtained were 376 male and 331 female blue swimming crabs. Based on the results of $t$-test, the correlation between carapace width body weight of blue swimming crabs showed isometric growth pattern of both male and female, with a strong coefficient correlation. Those blue swimming crabs were analyzed and were found into three age groups (cohorts). Those blue swimming crabs were dominant in the cohort of cacapace wide average of $91.92 \mathrm{~mm}$. Population parameters of $\mathrm{L} \infty, \mathrm{K}$, and $\mathrm{t}_{0}$ of male and female blue swimming crab were quite different, namely $\mathrm{CW}_{\infty}$ of $155.76 \mathrm{~mm}, \mathrm{~K}$ of 0.83 /year, and $\mathrm{t}_{0}$ of -0.126 for males, while $\mathrm{CW}_{\infty}$ of $184.82 \mathrm{~mm}, \mathrm{~K}$ of $0.43 /$ year, and $\mathrm{t}_{0}$ of -0.231 for males. Those data showed that blue swimming crab in this waters should be maintained and well managed its surrounding due to $\mathrm{K}$ value of both sexes are quite low and will take time to reach those $\mathrm{CW}_{\infty}$ value of both sexes. It is hoped that the data in this study may be used to management formulation of blue swimming crabs in the Toronipa waters in order to sustain its population.
\end{abstract}

Keywords: Size structure, Population parameter, Portunus pelagicus, Toronipa waters.

\begin{abstract}
ABSTRAK
Penelitian ini bertujuan untuk menganalisis struktur ukuran dan parameter populasi rajungan ( $P$. pelagicus) di perairan Toronipa yang dilakukan pada bulan Maret sampai Agustus 2014. Total sampel yang diperoleh adalah 376 ekor rajungan jantan dan 331 ekor rajungan betina. Kelas ukuran lebar karapas rajungan yang banyak tertangkap selama penelitian berkisar $95,84 \mathrm{~mm}-106,35 \mathrm{~mm}$ untuk jantan dan 90,97 mm - 105,15 mm untuk betina. Data lebar karapas rajungan yang diperoleh dianalisis dan ditemukan 3 rata-rata kelompok ukuran (kohort). Ukuran lebar karapas rajungan tersebut dominan berada pada rata-rata 91,92 mm. Parameter populasi $\mathrm{CW}_{\infty}, \mathrm{K}$, and $\mathrm{t}_{0}$ rajungan jantan dan betina terdapat kecenderungan nilai yang berbeda, yaitu $\mathrm{CW}_{\infty}=155,76 \mathrm{~mm}$, $\mathrm{K}=0,83$ /year, dan $\mathrm{t}_{0}=-0,126$ untuk rajungan jantan, sedang $\mathrm{CW}_{\infty}=184,82 \mathrm{~mm}, \mathrm{~K}=0,43 /$ year, dan $\mathrm{t}_{0}=-0,231$ untuk betina. Data parameter populasi rajungan tersebut mengindikasikan bahwa rajungan di perairan ini diusahakan dijaga/dipelihara dan dikelola baik karena nilai $\mathrm{K}$ kedua jenis kelamin relatif rendah dan akan membutuhkan waktu lama untuk mencapai nilai $\mathrm{CW}_{\infty}$ kedua jenis kelamin. Diharapkan data dalam penelitian ini dapat menjadi bahan merumuskan pengelolaan rajungan agar supaya populasinya dapat dipertahankan.
\end{abstract}

Kata Kunci:Struktur ukuran, Parameter populasi, Portunus pelagicus, Perairan Toronipa.

DOI: http://dx.doi.org/10.33772/jspi.v1n1.xxxx 


\section{PENDAHULUAN}

Sulawesi Tenggara merupakan salah satu daerah sumber bahan baku industri pengalengan daging rajungan. Penangkapan rajungan di perairan Sulawesi Tenggara terus meningkat setiap tahun sehingga populasinya telah menunjukan penurunan (La Sara et al. 2016a; 2016b). Data hasil tangkapan rajungan tahun 2014 memperlihatkan bahwa beberapa daerah telah terjadi peningkatan produksi tangkapan rajungan seperti di Buton pada tahun 2009 - 2012 menunjukan peningkatan dari 26,9 ton menjadi 63 ton, di Muna pada tahun 2009 - 2014 meningkat dari 321,4 ton menjadi 421,6 ton, di Konawe pada tahun 2009 - 2011 meningkat dari 99,3 ton menjai 100,9 ton, dan di Konawe Selatan pada tahun 2009 - 2011 meningkat dari 41,8 ton menjadi 47,2 ton (Dinas Kelautan dan Perikanan Provinsi Sulawesi Tenggara, 2014).

Berkurangnya jumlah populasi rajungan karena tingginya penangkapan yang ditandai dengan semakin berkurangnya hasil tangkapan, ukuran rajungan yang tertangkap semakin kecil dan fishing ground yang semakin jauh (La Sara et al. 2016c). Selain itu, apabila habitatnya mendapat gangguan berat dapat merubah struktur populasinya bahkan dapat menyebabkan kepunahan (Juwana, 2004; Wiadnya et al, 2005). Oleh karena itu, diperlukan suatu kajian mengenai beberapa parameter populasi rajungan sebagai bahan informasi dasar dalam penentuan atau perencanaan model pengelolaan sumber daya rajungan agar pemanfaatannya tetap lestari.

\section{METODE PENELITIAN}

\section{Lokasi Studi}

Penelitian dilaksanakan di perairan Toronipa yang merupakan wilayah administrasi Kecamatan Soropia, Konawe. Lokasi ini berada pada posisi geografis $3^{0} 53^{\prime} 31^{\prime \prime}-3^{0} 53^{\prime} 63^{\prime \prime}$ BT dan $122^{0} 39^{\prime} 67^{\prime \prime}$ $122^{\circ} 40^{\prime} 07^{\prime}$ 'LS. Perairan ini mempunyai topografi landai yang banyak ditumbuhi lamun. Perairan ini berbatasan langsung dengan Laut Banda sehingga pada saat musim timur jumlah trip penangkapan rajungan berkurang karena angin yang bertiup sangat kuat yang diikuti dengan badai dan gelombang cukup tinggi.
Perairan Toronipa ditumbuhi lamun yang kerapatannya relatif homogen dengan substrat lumpur berpasir yang memungkinkan rajungan dapat membenamkan diri pada saat tidak beraktivitas, terutama pada saat molting.

\section{Pengumpulan Data}

Penentuan lokasi pengambilan sampel rajungan ditentukan secara purposif, yaitu pada daerah yang dianggap tempat atau jalur rajungan untuk mencari makan. Pengamatan kerapatan lamun dibagi tiga stasiun yang diasumsikan mewakili daerah penangkapan. Pengambilan sampel rajungan menggunakan bubu berbentuk kubus dengan ukuran panjang $50 \mathrm{~cm}$, lebar $25 \mathrm{~cm}$, dan tinggi $25 \mathrm{~cm}$. Rangka bubu terbuat dari besi dibungkus dengan jaring nilon mesh size 1 inci. Bubu yang digunakan sebanyak 50 unit dan dibagi menjadi dua rangkaian sehingga tiap rangkaian terdapat 25 unit. Jarak antar bubu $5 \mathrm{~m}$ dengan panjang tali ke pelampung sepanjang $10 \mathrm{~m}$. Pengumpulan sampel rajungan dilakukan setiap minggu selama enam bulan. Setiap rajungan yang tertangkap baik dari hasil tangkapan sendiri maupun hasil tangkapan nelayan dikumpulkan untuk diidentifikasi jenis kelaminnya, diukur dan dicatat lebar karapas dan berat basah tubuh berdasarkan jenis kelamin (Potter dan de Lestang, 2000; Sawusdee dan Songrak, 2009; Kamrani, et al, 2010; La Sara et al. 2016a). Lebar karapas (CW/carapace width) diukur lurus dari sisi duri terluar bagian kiri sampai bagian duri kanan menggunakan jangka sorong (ketelitian 0,05 mm). Bobot basah individu diukur per individu menggunakan timbangan analitik (ketelitian 0,01 g) (Kamrani et al., 2010; Syahrir, 2011; La Sara et al. 2016a).

\section{Analisis Data}

Data morfometrik yang diperoleh dianalisis untuk mengetahui hubungan lebar karapas dan bobot tubuh rajungan menggunakan persamaan Ricker (1975); La Sara (2001) sebagai berikut:

$$
\mathrm{W}=\mathrm{aL}^{\mathrm{b}}
$$

Persamaan dapat ditransformasi kedalam bentuk regresi linear sederhana (Hartnoll, 1982) sebagai berikut:

$$
\log \mathrm{W}=\log \mathrm{a}+\mathrm{b} \log \mathrm{L}
$$

keterangan: $\mathrm{W}=$ bobot total rajungan $(\mathrm{g}), \mathrm{L}=$ lebar karapas $(\mathrm{mm})$, a dan $\mathrm{b}=$ konstanta.

Nilai $b$ adalah koefisien pertumbuhan yang digunakan sebagai penduga pola pertumbuhan yang 
disebabkan oleh parameter lebar karapas dan bobot tubuh (King, 2007; Sawusdee and Songrak, 2009).

Untuk mendapatkan pembagian kelompok umur (kohort) berdasarkan kelompok ukuran menggunakan metode Bhattacharya dan NORMSEP yang terdapat dalam program FiSAT (Sparre dan Venema, 1999).

Pendugaan parameter pertumbuhan $\mathrm{CW}_{\infty}$ (lebar asymptotic, $\mathrm{mm}$ ) and $\mathrm{K}$ (koefisien laju pertumbuhan, year $^{-1}$ ) digunakan program ELEFAN (Elektronic Length Frequency Analysis) yang terdapat di dalam paket program FiSAT.

Parameter pertumbuhan $\left(\mathrm{CW}_{\infty}\right.$ dan $\left.\mathrm{K}\right)$ yang digunakan untuk menduga persamaan pertumbuhan von Bertalanffy (von Bertalanffy, 1938; Beverton dan Holt, 1957), $\mathrm{CW}_{\mathrm{t}}=\mathrm{CW}_{\infty}\left(1-\mathrm{e}^{-\mathrm{k}(\mathrm{t}-\mathrm{to})}\right)$ dapat dihitung dari data distribusi lebar karapas menggunakan program ELEFAN yang terdapat di dalam paket program FiSAT (Gayanilo et al., 1996 ; La Sara, 2010).

Parameter pertumbuhan $\mathrm{t}_{0}$ dapat dihitung dari persamaan Pauly (1980) berikut:

$\log \left(-\mathrm{t}_{0}\right)=-0,3922-0,2752 \times \log \left(\mathrm{L}_{\infty}\right)-1,038 x \log (\mathrm{K})$ keterangan: $\mathrm{t}_{0}=$ umursaat $0 \mathrm{~mm}, \mathrm{~K}$ dan $\mathrm{L} \infty=$ parameter pertumbuhan von Bertalanffy.

Pendugaan terhadap koefisien kematian alami (M) menggunakan persamaan empiris Pauly (1980):

$\log (\mathrm{M})=-0,0066-0,279 \log \mathrm{L}_{\infty}+0,6543 \log \mathrm{K}$ $+0,463 \log \mathrm{T}$

keterangan: $\mathrm{K}$ dan $\mathrm{L} \infty=$ parameter pertumbuhan von Bertalanffy, $\mathrm{T}=$ suhu rata-rata tahunan.

Nilai mortalitas total $(\mathrm{Z})$ dihitung menggunakan kurva hasil tangkapan yang dikonversi ke lebar karapas (width-converted catch curve) (Sparre dan Venema, 1999). Nilai koefisien dari mortalitas penangkapan (F) diperoleh dengan menggunakan rumus:

$$
\mathrm{F}=\mathrm{Z}-\mathrm{M}
$$

keterangan: $\mathrm{F}$ adalah mortalitas penangkapan, $\mathrm{Z}=$ mortalitas total, $\mathrm{M}=$ mortalitas alami

Penentuan tingkat ekploitasi dapat diduga mellaui persamaan Sparre dan Venema (1999):

$$
\mathrm{E}=\mathrm{F} / \mathrm{Z}
$$

keterangan: $\mathrm{E}=$ status eksploitasi, $\mathrm{F}=$ mortalitas penangkapan, $\mathrm{Z}=$ mortalitas total.

Jika nilaiE > 0,5 menunjukkan tingkat eksploitasi tinggi (over fishing), $\mathrm{E}=0,5$ menunjukkan pemanfaatan optimal (E opt), dan $\mathrm{E}<0,5$ menunjukkan tingkat eksploitasi rendah (under fishing) (Gulland, 1977). Pola rekrutmen didapatkan melalui analisis menggunakan program FISAT II pada sub program recruitment pattern dengan memasukkan nilai $\mathrm{CW}_{\infty}, \mathrm{K}$, dan $\mathrm{t}_{0}$ yang telah dihitung sebelumnya.

\section{HASIL DAN PEMBAHASAN}

\section{Hasil}

\section{Struktur Ukuran dan Kelompok Umur}

Kisaran lebar karapas rajungan jantan dan betina pada bulan Maret - Agustus masing-masing 53,75 $153,60 \mathrm{~mm}$ (rata-rata 103,69 $\mathrm{mm}$ ) dan 48,40 $180,50 \mathrm{~mm}$ (rata-rata $107,31 \mathrm{~mm})$ (Gambar 1).
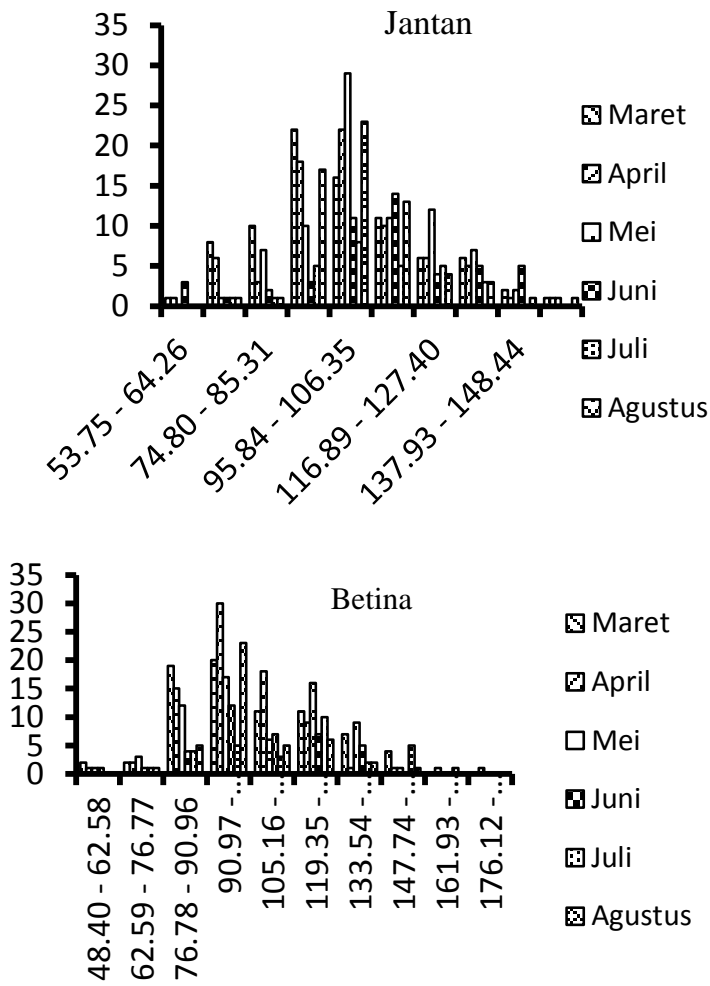

Gambar 1. Histogram frekuensi lebar karapas rajungan di Perairan Toronipa

Kelompok ukuran total rajungan yang diperoleh tersebut setelah dianalisis diperoleh tiga kelompok umur (kohort) (Gambar 2). Perubahan kelompok umur setiap bulan dari Maret sampai Agustus juga disajikan (Gambar 2).

\section{Hubungan Bobot Tubuh (W) - Lebar Karapas (CW)}


Sample rajungan yang diperoleh selama penelitian adalah 707 individu yang terdiri atas 376 jantan dan 331 betina. Hubungan bobot tubuh dan lebar karapas rajungan disajikan pada Tabel 1 dan Gambar 3.
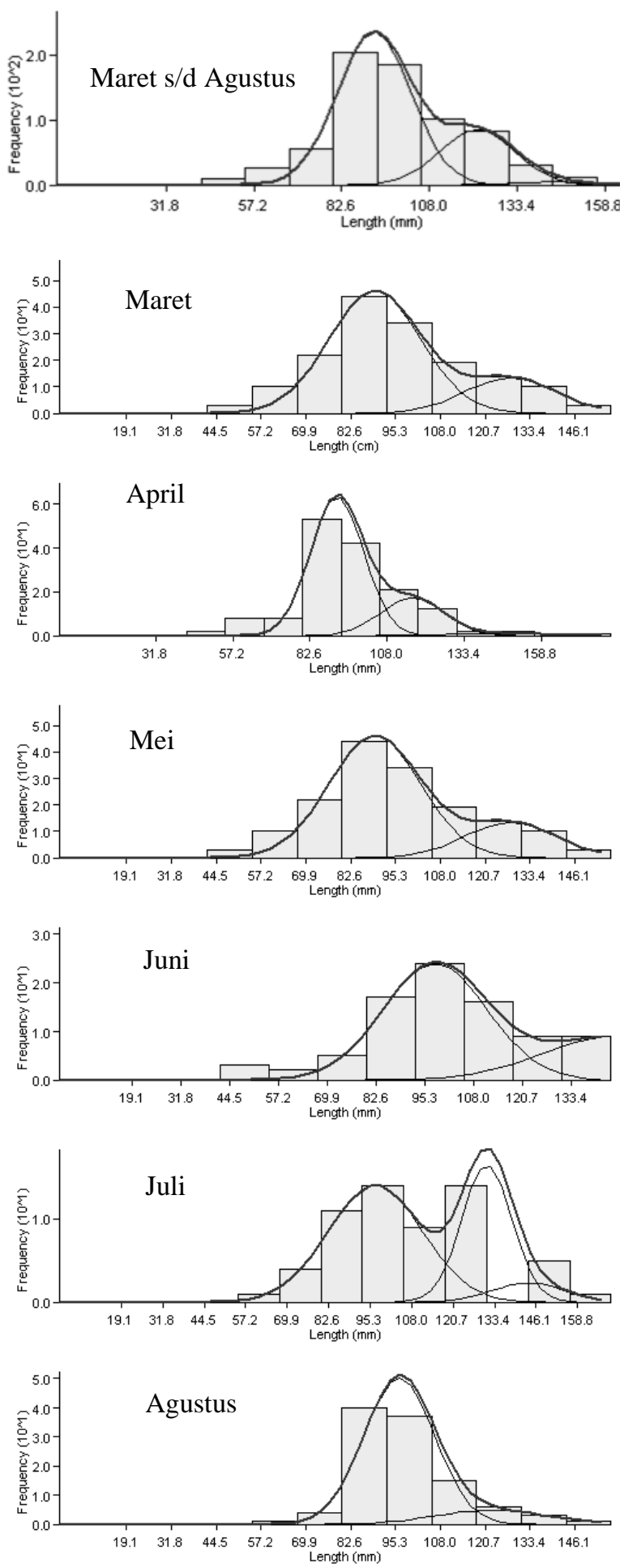

Gambar 2. Kelompok umur (kohort) rajungan di perairan Toronipa

Tabel 1. Hubungan bobot (W) - lebar karapas (CW) rajungan.

\begin{tabular}{ccccc}
\hline Kelamin & $\begin{array}{c}\text { Jumlah } \\
\text { (ekor) }\end{array}$ & Persamaan & R & $\begin{array}{c}\text { Pola } \\
\text { pertumbuhan* }\end{array}$ \\
\hline Jantan & 376 & $\mathrm{~W}=-4,379 \mathrm{~L}^{3,105}$ & 0,967 & Isometrik \\
Betina & 331 & $\mathrm{~W}=-4,032 \mathrm{~L}^{2,926}$ & 0,944 & Isometrik \\
\hline * uji-t $\mathrm{p}<0.05$ & & &
\end{tabular}
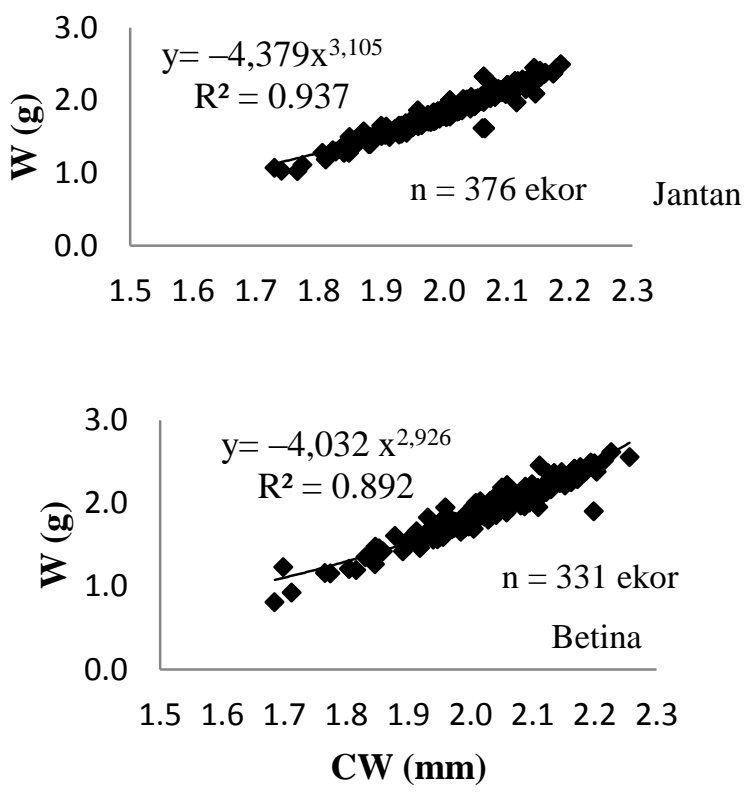

Gambar 3. Jenis kelamin jantan dan betina

\section{Parameter Pertumbuhan}

Nilai parameter pertumbuhan von Bertalanffy rajungan jantan dan betina di perairan Toronipa menunjukan perbedaan menyolok (Tabel 2).

Tabel 2. Nilai parameter pertumbuhan rajungan di Perairan Toronipa.

\begin{tabular}{ccccc}
\hline Kelamin & $\mathrm{CW}_{\infty}(\mathrm{mm})$ & $\begin{array}{c}\mathrm{K} \\
\left.\operatorname{tahun}^{-1}\right)\end{array}$ & $\begin{array}{c}\mathrm{t}_{0} \\
(\text { tahun })\end{array}$ & $\begin{array}{c}\text { Persamaan } \\
\text { Pertumbuhan }\end{array}$ \\
Jantan & 155,76 & 0,830 & $-0,1266$ & $\left.\begin{array}{c}\mathrm{CW}_{\mathrm{t}}=155,760\left(1-\mathrm{e}^{-}\right. \\
0,830(\mathrm{t}+0,1266)\end{array}\right)$ \\
Betina & 184,82 & 0,430 & $-0,2314$ & $\begin{array}{c}\mathrm{CW}_{\mathrm{t}}=184,820\left(1-\mathrm{e}^{-}\right. \\
0,430(\mathrm{t}+0,2314)\end{array}$ \\
\hline
\end{tabular}

\section{Pembahasan}

\section{Struktur Ukuran dan Kelompok Umur}


Kelas ukuran lebar karapas rajungan jantan dan betina yang banyak tertangkap selama penelitian masing-masing berkisar 95,84 - 106,35 $\mathrm{mm}$ dan 90,97 - 105,15 mm. Ukuran lebar karapas rajungan di perairan Toronipa termasuk kategori rajungan muda (60 - 120 mm) (Budiaryani, 2007 in Prasetyo et al., 2014). Rajungan muda lebih banyak didapatkan dibanding dengan rajungan dewasa karena perbedaan kondisi lingkungan yang sesuai dengan siklus hidup rajungan. Hosseini et al. (2012) menyatakan bahwa di perairan pantai, kepiting muda ditemukan pada perairan yang lebih dangkal atau dekat dengan garis pantai, sedangkan kepiting dewasa, umumnya ditemukan di perairan yang lebih dalam sampai kedalaman $50 \mathrm{~m}$ dan salinitas lebih tinggi. La Sara and Astuti (2015) menyatakan bahwa rajungan muda khususnya rajungan jantan, lebih menyukai perairan dengan salinitas lebih rendah dibandingkan dengan rajungan lebih tua atau dewasa.

Pemisahan kelompok ukuran per bulan, diperoleh jumlah kelompok umur (kohort) yang berbeda-beda. Pada bulan Maret, Mei, Juni, dan Agustus terdapat dua kohort, sedangkan pada bulan April dan Juli terdapat tiga kohort. Jumlah kohort dalam suatu populasi menujukkan jumlah kelompok umur yang berbeda-beda dalam satu populasi. Artinya kelompok kohort yang paling tua akan menghasilkan organisme baru (proses reproduksi) untuk masuk ke dalam populasi tersebut (rekruitmen), sehingga kelompok umur yang lebih muda akan tumbuh menjadi dewasa (bertambah umur) dan terjadi regenerasi dalam populasi tersebut. Sekelompok generasi baru tersebut akan menjadi satu kohort yang baru pula.

Hasil analisis kelompok umur menunjukkan perbedaan antara jumlah observasi (707 individu) dan yang dianalisis (688 individu). Perbedaan jumlah rajungan ini disebabkan oleh ukuran lebar karapas yang seragam cukup banyak (18 - 26 individu) yang menumpuk pada satu kelompok yang mengakibatkan tidak bisa dipisahkan kelompok ukurannya. Masalah analisis tersebut juga dilihat dari nilai indeks separasi dari kelompok ukuran tidak memenuhi syarat $(\mathrm{I}<2)$ yaitu terdapat pada bulan Juli sehingga tidak memungkinkan dilakukan perhitungan secara tepat karena terjadi penumpukan ukuran rajungan yang sama. Nilai simpangan baku yang semakin besar menunjukkan bahwa sampel rajungan yang didapatkan selama penelitian semakin tua akan memiliki ukuran lebar karapas yang semakin beragam.
Kelompok umur rajungan yang paling banyak tertangkap memiliki ukuran lebar karapas rata-rata 91,92 mm. Lebar karapas tersebut menunjukan bahwa secara umum rajungan di perairan ini telah memasuki tingkat perkembangan "menuju dewasa" atau rajungan muda $(60-120 \mathrm{~mm})$. Nontji (1993) menjelaskan rajungan dalam siklus hidupnya mulai dari zoea sampai dewasa mengalami pergantian kulit sekitar 20 kali dan ukuran lebar karapasnya dapat mencapai $18 \mathrm{~cm}$ sehingga ukuran $7-15 \mathrm{~cm}$ secara umum dikategorikan ukuran rajungan dewasa.

\section{Hubungan Bobot Tubuh (W) - Lebar Karapas (CW)}

Hasil analisis koefisien regresi hubungan bobot tubuh dan lebar karapas diperoleh nilai b untuk jantan lebih besar dibandingkan betina (Tabel 1 dan Gambar 3). Hal ini menunjukkan bahwa pada ukuran lebar karapas yang sama, rajungan jantan relatif lebih berat dibandingkan rajungan betina. Keadaan ini dapat disebabkan oleh makanan rajungan jantan yang digunakan untuk pertambahan bobot dan ukuran tubuhnya, sedang makanan rajungan betina digunakan untuk pematangan gonad dan mengerami telur. Josileen (2011) menjelaskan bahwa pada crustacea betina yang sedang mengerami telur (berried female), pre-moult dan sedang proses pematangan gonad, mereka berhenti makan atau makan sangat sedikit. Kondisi tersebut juga dipengaruhi oleh perbedaan kebiasaan makan (Sukumaran dan Neelakantan, 1997a; Kangas, 2000) atau dapat juga disebabkan oleh kondisi geografis yang berbeda (La Sara et al., 2002). Beberapa hasil penelitian lain yang dilakukan pada berbagai daerah menunjukan nilai koefiesien regresi yang berbedabeda (Tabel 3).

Perbedaan-perbedaan pola pertumbuhan seperti di atas dapat disebabkan oleh pengaruh beberapa faktor, seperti perbedaan kondisi perairan atau habitat, ketersediaan makanan serta adanya kompetisi. La Sara et al. (2002) menjelaskan bahwa temuan seperti ini menunjukkan pola pertumbuhan kelas krustasea secara umum bervariasi antara genus dan spesies yang satu dengan yang lain. Masingmasing genus dan spesies memiliki pola pertumbuhan yang khas. Hal ini diduga tergantung pada kondisi habitat spesies.

Melihat nilai koefisien korelasi (r) antara lebar karapas dan bobot tubuh masing-masing rajungan jantan dan betina memiliki nilai cukup tinggi yaitu 
Ari Sandy Muchtar et al.

JURNAL SAINS dan INOVASI PERIKANAN / Journal of Fishery Science and Innovation

Vol. 1, No. 1, 1-8, Januari 2017

0,967 dan $0,944(\approx 1)$ yang berarti hubungan lebar karapas dan bobot tubuh memiliki hubungan yang tinggi. Nilai $r$ jantan lebih besar dari nilai betina, tetapi perbedaannya tidak signifikan. Hal ini disebabkan oleh pertumbuhan jantan yang relatif lebih stabil antara pertumbuhan lebar karapas dengan pertambahan bobot tubuhnya. Berbeda dengan rajungan betina, pertumbuhan betina akan tidak stabil saat memasuki masa-masa pemijahan (matang gonad), terutama pada saat rajungan betina sedang mengerami telur (bertelur), terjadi penambahan yang signifikan terhadap bobot tubuhnya sementara tidak ada pertambahan lebar karapas sehingga keeratan hubungan antara lebar karapas dan bobot tubuh rajungan menjadi menurun.

Tabel 3. Nilai hubungan bobot - lebar karapas family Crustacea di beberapa perairan.

\begin{tabular}{|c|c|c|c|c|}
\hline Spesies & b & $\mathbf{R}^{2}$ & Lokasi & Referensi \\
\hline \multicolumn{5}{|l|}{ P. pelagicus } \\
\hline - Jantan & 3,26 & - & Pesisir sebelah & Kangas \\
\hline - Betina & 3,05 & - & barat Australia & (2000) \\
\hline \multicolumn{5}{|l|}{ P. pelagicus } \\
\hline - Jantan & 2,75 & 0,93 & $\begin{array}{l}\text { Bandar, } \\
\text { Abhas Teluk }\end{array}$ & \\
\hline - Betina & 2,74 & 0,88 & $\begin{array}{l}\text { Abbas, I eluk } \\
\text { Persia, Iran }\end{array}$ & $\begin{array}{l}\text { et al., } \\
(2010)\end{array}$ \\
\hline \multicolumn{5}{|l|}{ P. pelagicus } \\
\hline - Jantan & 3,22 & 0,88 & Provinsi & Sawusdee \\
\hline - Betina & 3,18 & & $\begin{array}{l}\text { Trang, } \\
\text { Thailand }\end{array}$ & $\begin{array}{l}\text { dan } \\
\text { Songrak } \\
(2009)\end{array}$ \\
\hline \multicolumn{5}{|l|}{ P. pelagicus } \\
\hline - Jantan & 3,34 & 0,91 & Perairan Bone, & Ernawati \\
\hline - Betina & 3,26 & 0,89 & Indonesia & (2013) \\
\hline \multicolumn{5}{|l|}{ P. pelagicus } \\
\hline - Jantan & 3,48 & 0,98 & Perairan Bone, & Dineshbab \\
\hline - Betina & 3,22 & 0,93 & Indonesia & $\begin{array}{l}\text { u } \text { et al., } \\
\text { (2008) }\end{array}$ \\
\hline \multicolumn{5}{|l|}{ Scylla serrata } \\
\hline - Jantan & 2,95 & 0,92 & Teluk Lawelle, & La Sara $e t$ \\
\hline - Betina & 1,68 & 0,61 & Indonesia & al., (2002) \\
\hline
\end{tabular}

\section{Parameter Pertumbuhan}

Nilai $\mathrm{CW}_{\infty}$ rajungan betina $(184,82 \mathrm{~mm})$ lebih besar dari pada nilai $\mathrm{CW}_{\infty}$ jantan $(155,76 \mathrm{~mm})$. Lebar karapas maksimum rajungan jantan yang tertangkap adalah 153,60 mm, sedangkan rajungan betina mencapai 180,50 mm. Perbedaan ukuran lebar karapas yang tertangkap ini dipengaruhi oleh kondisi penangkapan yang berbeda-beda, seperti perbedaan lebar karapas $(\mathrm{CW})$ yang tertangkap.

Rajungan betina dengan lebar karapas 180,50 $\mathrm{mm}$ tersebut ditangkap di perairan yang lebih dalam dibandingkan dengan rajungan jantan dengan lebar karapas 153,60 mm yang umumnya ditangkap di perairan dangkal pada salinitas lebih rendah, sedangkan rajungan betina lebih menyukai perairan salinitas lebih tinggi. Rajungan betina yang sedang mengandung telur akan bermigrasi mencari perairan yang lebih dalam, salinitas perairan tinggi dan tekanan perairan yang lebih tinggi untuk melepaskan telur-telurnya.

Josileen dan Menon (2007) menunjukkan laju pertumbuhan rajungan betina lebih cepat dibandingkan rajungan jantan yang menunjukan sebaliknya dengan penelitian yang ditemukan di perairan Toronipa, yaitu laju pertumbuhan rajungan jantan $(0,830)$ lebih besar dibandingkan dengan laju pertumbuhan rajungan betina $(0,430)$. Nilai K yang relatif tinggi dan lebar karapas asimptotik yang lebih rendah adalah khas untuk sebagian besar spesies tropis (Pauly, 1984 in La Sara, 2010). Hal ini disebabkan oleh perbedaan proses metabolisme dalam memanfaatkan atau menyerap energi yang diperoleh dari makanan antara rajungan jantan dengan rajungan betina. Energi yang digunakan untuk perkembangan gonad dan mengerami telur oleh rajungan betina cukup besar sehingga menyebabkan energi untuk pertumbuhan ukuran tubuh menjadi terhambat, sehingga pertumbuhan lebar karapas rajungan jantan lebih cepat dibanding betina. Parameter pertumbuhan rajungan di perairan Toronipa cukup mirip dengan Family Portunidae lainnya misalnya S. serrata (La Sara, 2010).

Perbedaan nilai parameter pertumbuhan di beberapa lokasi di atas disebabkan oleh perbedaan kondisi lingkungan perairan dan tekanan penangkapan pada masing-masing lokasi. Ketersediaan pakan alami yang mencukupi pada habitanya akan menyebabkan pertumbuhan rajungan relatif lebih cepat karena persediaan energi yang dibutuhkan untuk melakukan proses-proses metabolisme tercukupi, sedang tekanan penangkapan yang tinggi menyebabkan terganggunya proses pertumbuhan rajungan. La Sara (2010) menambahkan bahwa ketersediaan makanan, temperatur, dan salinitas berpengaruh terhadap laju pertumbuhan. 


\section{KESIMPULAN}

Beberapa kesimpulan dalam penelitian adalah sebagai berikut:

1. Rajungan yang paling banyak tertangkap di perairan Toronipa selama penelitian berada pada kisaran ukuran lebar karapas 95,84 mm - 106,35 mm untuk jantan dan $90,97 \mathrm{~mm}-105,15 \mathrm{~mm}$ untuk betina.

2. Terdapat tiga kelompok umur (kohort) rajungan selama penelitian, dimana kelompok umur terbanyak memiliki lebar karapas rata-rata 91,92 $\mathrm{mm}$.

3. Pola pertumbuhan rajungan jantan dan betina yang diperoleh dari hasil analisis hubungan lebar karapas $(\mathrm{CW})$ dan bobot (W) mengikuti pola pertumbuhan isometrik $(b=3)$, walaupun nilai $r$ jantan lebih besar dibandingkan $r$ betina.

4. Lebar karapas asymptotic $\left(\mathrm{CW}_{\infty}\right)$ rajungan $(155,760 \mathrm{~mm})$ lebih kecil dibandingkan dengan $\mathrm{CW}_{\infty}$ betina $(184,820 \mathrm{~mm})$, walaupun demikian nilai koefisien $(\mathrm{K})$ rajungan jantan $(0,830)$ lebih besar dari $\mathrm{K}$ rajungan betina $(0,430)$.

\section{DAFTAR PUSTAKA}

Beverton, R.J.H. and Holt, S.J., 1957. On the Dynamics of Exploited Fish Populations. Fish Investment Series. Vol. 19. 533p.

Dineshbabu, A.P., Shridhara, B. and Muniyappa, Y., 2008. Biology and Exploitation of The Blue Swimming Crab, P. pelagicus (Linnaeus, 1758, from South Karnataka Coast, India. Indian Journal Fisheries. 55(3): 215 - 220.

Ernawati, T., 2013. Dinamika Populasi dan Pengkajian Stok Sumber Daya Rajungan $(P$. pelagicus) di Perairan Kabupaten Pati dan Sekitarnya. Tesis. Institut Pertanian Bogor. Bogor. 101 hal.

Gayanilo, F.C., P. Sparre and D. Pauly., 1996. FAOICLARM stock Assessment Tools (FISAT) User's guide. FAO Computerized Information Series (Fisheries), No 6. Rome FAO. 186p.

Gulland, J.A., 1977. Fish Population Dynamics. The Implications of Management. A WilleyInter Science Publication. $2^{\text {nd }}$ ed. John Willey and Sons Ltd. 102p.

Hartnoll, R. G., 1982. The Biology of Crustacea Academic. Press 2: 111 - 196.

Hosseini, M., A. Vazirizade., Y. Parsa., A. Mansori, 2012. Sex Ratio, Size Distribution and Seasonal
Abundance of Blue Swimming Crab, P.pelagicus (Linnaeus, 1758) in Persian Gulf Coasts, Iran. World Applied Sciences Journal, 17 (7): 919 - 925.

Josileen, J. and N. G. Menon, 2007. Fishery and growth parameters of the blue swimmer crab Portunus pelagicus (Linnaeus, 1758) along the Mandapam coast, India. Journal of the Marine Biological Association of India. 49 (2): 159 - 165.

Josileen, J., 2011. Food and Feeding of The Blue Swimming Crab, $P$. pelagicus (Linneaeus, 1758) (Decapoda, Brachyura) Along The Coast of Mandapam Tamil Nadu, India. Crustaceana. 84(10): 1169 - 1180.

Juwana, S., 2004. Penelitian Budi Daya Rajungan dan Kepiting: Pengalaman Laboratorium dan lapangan, Prosiding Simposium Interaksi Daratan dan Lautan.Lembaga Ilmu Pengetahuan Indonesia. Jakarta.

Kamrani, E., Sabili, A.N., Yahyavi, M., 2010. Stock Assessment and Reproductive Biology of the Blue Swimming Crab, Portunus pelagicus in Bandar Abbas Coastal Waters, Northern Persian Gulf. Journal of the Persian Gulf (Marine Science) 1(2): $11-21$.

Kangas, M.I., 2000. Synopsis of The Biologyand Exploitation of The Blue Swimming Crab, Portunus pelagicus Linnaeus, in Western Australia Fisheries Research Report No.121. http://www.fish.wa.gov.au.

King, M.G., 2007. Fisheries Biology, Assessment and Management. $2^{\text {nd }}$ Ed. Blackwell. UK. 382p.

La Sara, 2001. Ecology and Fisheries of Mud Crab (Scylla serrata) in Lawele Bay, Southheast Sulawesi, Indonesia. Ph.D. Dissertation College of Fisheries and Ocean Science, University of the Philippines, Miagao, Iloilo. Philippines.

La Sara, J. A. Ingles, R. B. Baldevarona, R. O. Aguilar, L. V. Laureta, and S. Watanabe. 2002. Reproductive Biology of Mud Crab Scylla serrata in Lawele Bay, Southeast Sulawesi, Indonesia. Crustacean Fisheries. 2002: 88 - 95.

La Sara, 2010. Study on the Size Structure and Population Parameters of Mud Crab Scylla serrata in Lawele Bay, Southeast Sulawesi, Indonesia. Journal of Coastal Development 13(2): 133 - 147.

La Sara and Astuti, O., 2015. Harvest control rules Rajungan ( $P$. pelagicus) in Sulawesi Tenggara 
Ari Sandy Muchtar et al.

JURNAL SAINS dan INOVASI PERIKANAN / Journal of Fishery Science and Innovation

Vol. 1, No. 1, 1-8, Januari 2017

waters. Paper presented in the $2^{\text {nd }}$ Marine and Fisheries National Symposium. Makassar, 9 May 2015.

La Sara, Muskita, W.H., Astuti, O., Safilu, 2016a. The Reproductive Biology of Blue Swimming Crab Portunus pelagicus in Southeast Sulawesi waters, Indonesia. AACL Bioflux. 9(5): 1101 1112.

La Sara, Halili., Mustafa, A., Bahtiar, 2016b. Appropriate Escape Vents Sizes on Collapsible Crab Pot for Blue Swimming Crab (Portunus pelagicus) Fishery in Southeast Sulawesi Waters, Indonesia. Journal of Fisheries and Aquatic Sciences, 11: 402 - 410. DOI: 10.3923/jfas.2016.

La Sara, Muskita, W. H, Astuti, O., Safilu, 2016c. Effort in Harvest Control Rule for the Blue Swimming Crab (Portunus pelagicus) in Southeast Sulawesi, Indonesia. Paper presented in the Crustacean Society Mid-Year Meeting 2016, 11 - 13 July 2016. National University of Singapore, Singapore.

Nontji, A. 1993. Laut Nusantara (cet. 2). Djambatan, Jakarta. 367 hal.

Pauly, D., 1980. A Selection of Simple Methods for The Assessment of Tropical Fish Stocks. FAO Fisheries Circular. No. 729. 54p.

Potter, I. C. and de Lestang S., 2000. Biology of The Blue Swimmer Crab (Portunus pelagicus) in Leschenault Estuary and Koombana Bay, South Western Australia. Journal of The Royal Society. Western Australia. 83: 443 - 458.

Prasetyo, G. D., A. D. P. Fitri, dan T. Yulianto, 2014. Analisis Daerah Penangkapan Rajungan ( $P$. pelagicus) berdasarkan perbedaan Kedalaman Perairan dengan Jaring Arad (Mini Trawl) di Perairan Demak. Journal of Fisheries Resources Utilization Management and Technology. 3(3): 257 - 266.

Ricker, W,E. 1975. Computation and Interpretation of Biological Statistic of Fish Population. Bulletin Fisheries Resources Board. Canada. $382 \mathrm{p}$.

Sawusdee, A. and Songrak, A. 2009. Population Dynamics and Stock Assessment of Blue Swimming Crab (Portunus pelagicus Linnaeus, 1758) in the Coastal Area of Trang Province, Thailand. Journal of Walailak Journal Science and Technology 6(9): 189 - 202.
Sparre, P. dan S. C. Venema, 1999. Indroduksi Pengkajian Stok Ikan Tropis (Edisi Bahasa Indonesia). FAO-Puslitbangkan. Jakarta. 436 hal. Terjemahan: J. Widodo, I.G.S. Merta, S. Nurhakim, dan M. Badrudin.

Sukumaran, K.K. and B. Neelakantan, 1997a. Length-Weight Relationship in Two Portuni Crabs, Portunus sanguinolentus (Herbst) and $P$. pelagicus (Linnaeus) from The Karnataka Coast. Indian. Journal of Marine Science, 26: 39 $-42$.

Sunarto, 2012. Karakteristik Bioekologi Rajungan ( $P$. pelagicus) di Perairan Laut Kabupaten Brebes [Disertasi]. Bogor (ID): Sekolah Pascasarjana, Institut Pertanian Bogor.

Syahrir, 2011. Strategi Pengelolaan Sumberdaya Perikanan Rajungan ( $P$. pelagicus) untuk Pemanfaatan Berkelanjutan (Kasus: Teluk Bone, Kabupaten Kolaka, Provinsi Sulawesi Tenggara). Tesis. Institut Pertanian Bogor. Bogor. 137 hal.

Von Bertalanffy, L., 1938. A Quantitative Theory of Organic Growth. Human Biology. 10:181 - 213.

Wiadnya, D.G.R., P.J. Mous, R. Djohani, M.V. Erdmann, A. Halim, M. Knight, L. PetSoede \& J.S. Pet 2005. Marine Capture Fisheries Policy Formulation and The Role of Marine Protected Areas as Tool for Fisheries Management in Indonesia. Marine Research. Indonesia 30: 33 45 . 